\title{
IRISH HISTORICAL THINKING IN THE SAGA \\ CATH MAIGE TUIRED CONGA
}

\author{
POTOPAEVA VERA
}

'The First Battle of Mag Tuired' is the title of one of the two sagas from the so-called mythological (or pseudo-historical) cycle. This place-name means "The plain of towers" or "The plain of pillars". Two great battles were allegedly fought on this plain: the first and the second battle of Mag Tuired. Our story is devoted to the first battle between the Fir Bolg and the Sons of Mil. This text survives in only one source: the manuscript H 2.17 from Trinity College Dublin library. The language of the source can be described as the Early Modern Irish with some Old and Middle Irish features, which is typical for Early Modern saga-texts. J. Fraser even suggests, that "we have here the result of several revisions of a text which may, in parts, go back to the early Middle Irish period" (Fraser 1915: 3). This text tells of the arrival of the Fir Bolg in Ireland and their ups and downs after the Túatha Dé Danann invasion. According to Walsh (1947: 119), the scribe and probably the compiler of our text was Cormac Ó Cuirnín, a member of Ó Cuirnín family, one of the learned families of Connacht.

I would like to show the importance of time and space in this text, specifically the way the compiler imagined the chronotope of his narration. Chronotope, as Mikhail Bakhtin remarked, is "the intrinsic connectedness of temporal and spatial relationships that are artistically expressed in literature" (Bakhtin 1981: 84).

First of all we need to assess the author's knowledge of the world's geography. The sons of Nemed, who were the ancestors of the Fir Bolg, lived in Ireland and paid the high tribute to the Fomorians. They decided to leave the island and to look for a better life. They sailed to Greece, or, according to another version, they were brought there by the strong wind. The sons of Nemed settled there, but the inhabitants of Greece wronged and oppressed them. So they had to leave Greece too. They used their leather bags as makeshift boats (this micro-plot provides a popular etymological explanation of the meaning of the name "Fir Bolg" - "the men of bags") and in addition they stole some ships from the Greeks. They decided to return to Ireland, and on their way back they passed through Spain. For centuries, the European Christian tradition served as the foundation and backdrop for Irish historiography, hagiography, poetry and political thought (Carey 1994: 2). This itinerary of the Fir Bolg's journey was probably influenced by the 
writings of St. Isidore of Seville, an authority for the Irish medieval literati, who taught that Spain was "the mother of all nations":

Omnium terrarum, quaeque sunt ab occiduo usque ad Indos, pulcherrima es, o sacra, semperque felix principum, gentiumque mater Hispania $^{1}$ (Isidorus Hispalensis 1950: col.1057-8).

The description of their return voyage is slightly confused. The author mentions that the Fir Bolg travelled from Greece to Spain for three long years, and yet it took them only thirteen days to get from Spain to Ireland. In real life, those two distances are comparable. The author was probably ignorant of the real geography of Europe, but we must also take into account his specific mentality. Space and time in his text are distorted; they do not correspond with reality (Carey 1990: 28). This distorted space and time are the elements of a mythological chronotope which was created by the author with a mythological worldview.

If we look through the Irish toponyms, which are connected with the arrival of the Fir Bolg, we find that those are mostly the river mouths on the east and south-east coast of the island. Invaders are usually depicted as arriving to Ireland by the river mouth (OIr. inber), which had a symbolic as well as practical meaning. Of course, the river mouth is the most convenient place to land, but for the people who were separated from the whole world by the sea or ocean the river mouth also had symbolic status as the gates into Ireland.

The Fir Bolg domesticated the space around them. Estuaries and bays served as the natural boundaries between the lands they were about to conquer. They were the first men who divided Ireland into five parts, established the royal power there and also made themselves the first kings of the island (O’Rahilly 1946: 47).

One of those fifths (OIr. cóiceda), Connacht, drew the complier's attention by the reason of its connection with the Fir Bolg. This tribe acted in this text like "culture-heroes". They taught the Greeks how to cultivate land and brought sheep to Ireland. There is no other text in the Irish pseudohistorical tradition where the Fir Bolg play a comparable role. The reason for this importance could also be the connection between the Ó Cuirnín family and the royal dynasties of Connacht and Breifne (Ó Conchobhair, Ó Ruairc) (Walsh 1947: 132). His main aim was to tell the story about the legendary ancestors of the medieval inhabitants of Connacht.

\footnotetext{
1 'Of all lands which stretch from the West to India you are the most beautiful, O Spain, sacred and ever-blessed mother of leaders and of nations' (Isidore of Seville 1966: 1).
} 
Finally we discuss a question of the localisation of this battle. There are some different points of view on this problem, but we think that the compiler of the text located it in County Mayo, near the Abbey of Cong. The following arguments may be produced in favour of this view:

1. The Abbey of Cong was an ancient cultural centre where the tradition of historical writing and the recording of annals was maintained after the Norman invasion (Healy 1905: 14).

2. The Abbey of Cong was also a political and ideological centre, closely connected with the royal dynasty of O'Connor.

3. The landscape of the plain, described in the saga, reminds one of the real landscape at the plain of Moytura in County Mayo. There are a lot of pre-historic monuments there, which could have been associated in the Middle Ages with the tomb-stones and grave-stones of the Fir Bolg and the Túatha Dé Dannan (Lohan 1990: 77).

The localisation of this legendary battle is a problem of great importance, because it reflects the views of the compiler and his connection with some cultural and ideological centers. This research in the field of time and space helps us to reconstruct the mental map of the compiler.

Lomonosov Moscow State University

\section{References}

Bakhtin, M. M., 1981, The Dialogic Imagination: Four Essays, Austin.

Carey, J., 1990, 'Time, Memory and the Boyne Necropolis', Proceedings of the Harvard Celtic Colloquium 10, 24-36.

Carey, J., 1994, The Irish National-Origin Legend: Synthetic Pseudo-history, Cambridge.

Fraser, J., ed., 1915, 'The First Battle of Moytura', Eriu 8, 1-63.

Healy, J. 1905, 'Two Royal Abbeys by the Western Lakes: Cong and Inismaine', Journal of the Royal Society of Antiquaries of Ireland 15, 1-20.

Isidore of Seville, 1966, History of the Kings of the Goths, Vandals, and Suevi, Leiden.

Isidorus Hispalensis, 1950, Historia Gothorum, Wandalorum, Sueborum, in: Patrologia Latina 83.

Lohan, M., 1999, 'Ceremonial Monuments in Moytura, Co. Mayo', Journal of the Galway Archaeological and Historical Society 51, 77-108.

O'Rahilly, T.F., 1946, Early Irish History and Mythology, Dublin.

Walsh, P., 1947, Irish Men of Learning, Dublin. 